\title{
Erratum to: New tetranucleotide microsatellite loci in pink abalone (Haliotis corrugata) isolated via 454 pyrosequencing
}

\author{
A. P. Greenley $\cdot$ A. Munguia-Vega $\cdot$ \\ A. Saenz-Arroyo $\cdot$ F. Micheli
}

Published online: 13 October 2011

(C) Springer Science+Business Media B.V. 2011

Erratum to: Conservation Genet Resour

DOI 10.1007/s12686-011-9521-5

Please note the correct spelling of the second author's surname is Munguia-Vega.

The online version of the original article can be found under doi:10.1007/s12686-011-9521-5.

A. P. Greenley $(\bowtie) \cdot$ F. Micheli

Hopkins Marine Station, Stanford University,

120 Oceanview Blvd, Pacific Grove, CA 93950, USA

e-mail: greenley@stanford.edu

A. Munguia-Vega

Conservation Genetics Laboratory, School of Natural Resources

and the Environment, The University of Arizona,

BioSciences East 317, Tucson, AZ 85721, USA

\section{A. Saenz-Arroyo}

Comunidad y Biodiversidad A.C., Blvd. Agua Marina \#297,

Entre Jaiba y Tiburón, Colonia Delicias, 85420 Guaymas,

Sonora, Mexico 